\title{
Climate change impacts on discharges of the Rhone River in Lyon by the end of the twenty-first century: model results and implications
}

\author{
Virginia Ruiz-Villanueva $\cdot$ Markus Stoffel $\cdot$ \\ Gianbattista Bussi · Félix Francés · Christian Bréthaut
}

Received: 14 May 2014/Accepted: 6 October 2014/Published online: 25 October 2014

(C) Springer-Verlag Berlin Heidelberg 2014

\begin{abstract}
We assess possible modifications in the hydrological behaviour of the Rhone River and its tributaries at Lyon (France). We identify changes during the late-twentieth century based on observations and characterise potential impacts of climatic changes on river response by the end of the century. Different scenarios of the latest generation of IPCC AR5 CMIP5 and hydrological modelling were used and included two scenarios for future outlet discharge of Lake Geneva (Switzerland). We show that discharges in the Rhone basin are likely to decrease significantly by the end of the century and that the seasonality of run-off will change substantially as well. In
\end{abstract}

Electronic supplementary material The online version of this article (doi:10.1007/s10113-014-0707-8) contains supplementary material, which is available to authorized users.

V. Ruiz-Villanueva $(\bowtie) \cdot$ M. Stoffel

Dendrolab.ch, Institute of Geological Sciences, University of

Bern, Baltzerstrasse 1+3, 3012 Bern, Switzerland

e-mail: virginia.ruiz@dendrolab.ch

M. Stoffel

Climatic Change and Climate Impacts, Institute for

Environmental Sciences, University of Geneva, 1227 Carouge,

Switzerland

G. Bussi

School of Geography and the Environment, University of

Oxford, OX1 3QY Oxford, UK

F. Francés

Research Institute of Water and Environmental Engineering,

Universitat Politècnica de València, Camino de Vera s/n,

46022 Valencia, Spain

C. Bréthaut

Politics, Environment and Territories, Institute for

Environmental Sciences, University of Geneva, 1227 Carouge,

Switzerland addition, projections point to smaller discharge during low flows, but higher low flows in its sub-basins. Regarding floods, high flows exhibit a general tendency to decrease, whereas potential upwards can be observed for the more extreme floods (less frequent). The approach reported in this paper will help to reflect on the governance modalities of a transboundary river such as the Rhone, especially when water management depends on concession contracts, which are usually granted for several decades and typically last between 60 and 90 years.

Keywords Climate change - Water resources - Floods . Droughts $\cdot$ River management $\cdot$ Rhone River

\section{Introduction}

Management of water resources is a research priority, which goes beyond the simple understanding of how to use water. Today's water management encompasses the entire range of natural processes and complex dynamics that characterise water systems (European Union publications, 2013). This is even more so true when the resource is shared in a transboundary context and between two countries, as in the case of the Rhone River Basin (Bréthaut and Pflieger 2013). While the management of the River was partly delegated to hydropower companies and public stakeholders, the French and Swiss Governments have also started to look for new ways of managing the entire Rhone basin. One of the key challenges in transboundary river management is related to climate change and the impacts that warming temperatures and changes in precipitation may have on future run-off, in relation to the forces of interdependencies, and the complexity of interrelated physical and socio-economic systems. Over the last few 
decades, a large set of studies has been devoted to the impacts of climatic changes in the Alps in general (Gobiet et al. 2013) and on the Rhone River in particular (Deneux 2002; Redaud et al. 2002; Husting et al. 2005; Etchevers 2002; Beniston et al. 2011). The Swiss reach of the Rhone River has been analysed in the EU-FP7 project ACQWA (Beniston and Stoffel 2013) up to 2050 by using projections from the Climate Model Intercomparison Project 3 (CMIP3; Nakicenovic et al. 2000). In French Rhone basin, Explore2070 evaluated possible impacts of future climatic and socio-economic changes on water bodies and biodiversity by 2070 by using CMIP3 climate scenarios. The main findings of the ACQWA and Explore2070 projects were strong reductions in future discharges.

The challenge of our study was to add new lines of evidence to the above-mentioned research by (1) using the latest generation of IPCC AR5 climate scenarios (CMIP5; Taylor et al. 2012), and by (2) linking the Swiss and French basins through the inclusion of the management scheme of Lake Geneva in the catchment modelling. Conducting a climate change analysis at this temporal scale has been motivated by governance issues between the two countries and the negotiation of water right and concessions with lifetimes of up to 90 years. In particular, we (3) explore possible modifications in the hydrological behaviour of the Rhone River from Lake Geneva to Lyon, including all French tributaries upstream of Lyon, during the recent past (late-twentieth century) and (5) characterise potential impacts of climatic changes on river response by 2100 . We define two scenarios for the regulated outlet discharge from Lake Geneva and assume that discharge from the lake will change due to the predicted reduction of inflow (50-75\%; Beniston 2012).

\section{Study site}

The entire Rhone River Basin covers a surface of $98,500 \mathrm{~km}^{2}$ at its mouth near Marseille. It is mainly an Alpine river with $50 \%$ of the catchment above 500 masl and $15 \%$ above 1,500 masl. The focus of this work is on one particular perimeter of the catchment comprised between Lake Geneva (Switzerland) and Lyon (France), which covers approximately $50,000 \mathrm{~km}^{2}$ (Fig. 1).

Lake Geneva is one of the largest freshwater bodies in Western Europe $\left(582 \mathrm{~km}^{2}\right.$, storage capacity of 89 million $\mathrm{Hm}^{3}$ and drainage area of $7,975 \mathrm{~km}^{2}$ ). The Swiss watershed from the source of the Rhone River to Lake Geneva is dominated by a glacio-nival regime (with a glaciated area of $10 \%$ ), and around $50 \%$ of the annual precipitation falls in the form of snow. Twenty dams including eleven high-head hydropower plants exist in this part of the basin. Most of them were built in the mid-twentieth century (between 1951 and 1975). They control an area of 1,400 $\mathrm{km}^{2}$ and store $1,150 \mathrm{~mm}^{3}$ in summer, and release it in winter to produce peak power. The dams mainly impact the annual cycle of the Rhone without water consumption, the total volume of the water remains unchanged at the annual scale (Grandjean 1990; Rahman et al. 2012).

The level of Lake Geneva and the discharge at its outlet are regulated at Seujet dam in the city of Geneva. Since the construction of the dam, finalised in 1995, water level has been much more stable, with a maximum (372.3 masl) reached in summer and a minimum (371.70 masl) in March-April. In addition, once every 4 years, lake level is lowered to 371.50 masl to allow for maintenance and rehabilitation of structures located at the edge of lake (Canton Geneva 2014).

Lake regulation and hydropower operation at the outlet of Lake Geneva cause a change in the regime of the Rhone River, which thus loses part of its ice and snow-fed regime towards a smoothed seasonal variability. The impacts of lake regulation and hydropower at the outlet of the lake are somewhat compensated by the glacio-nival regime of the Arve River, which joins the Rhone immediately downstream of Lake Geneva. However, the discharge of the Arve has been reduced significantly since the 1980s. The regime of the Rhone River downstream of Lake Geneva is therefore depending on the regulation of the lake at the outlet and on discharge in the downstream tributaries. For this reason, we do not include the upstream watershed in our hydrological modelling, as it is hydrologically disconnected from the downstream part, but we consider Lake Geneva outflows as a boundary condition.

\section{Materials and methods}

We first explore the recent past to detect possible trends in the hydrological regime and secondly, based on future climatic scenarios, characterise river response to climate change up to 2100 by means of a distributed hydrological model. The human influence on water resources has not been taken into account, with the exception of Lake Geneva for which outflow is modelled using the current operational scheme at Seujet.

Input data

The ASTER-30 m DEM was used to extract topographic information (elevation, slope) and to estimate hydrological factors such as flow direction and flow accumulation, whereas the European Soil Database (ESDB; Panagos 2006) helped to estimate soil parameters. All input parameters for the hydrological model were inferred following the method proposed by Bussi et al. (2014). For the vegetation classification, the Corine Land Cover 2006 and 


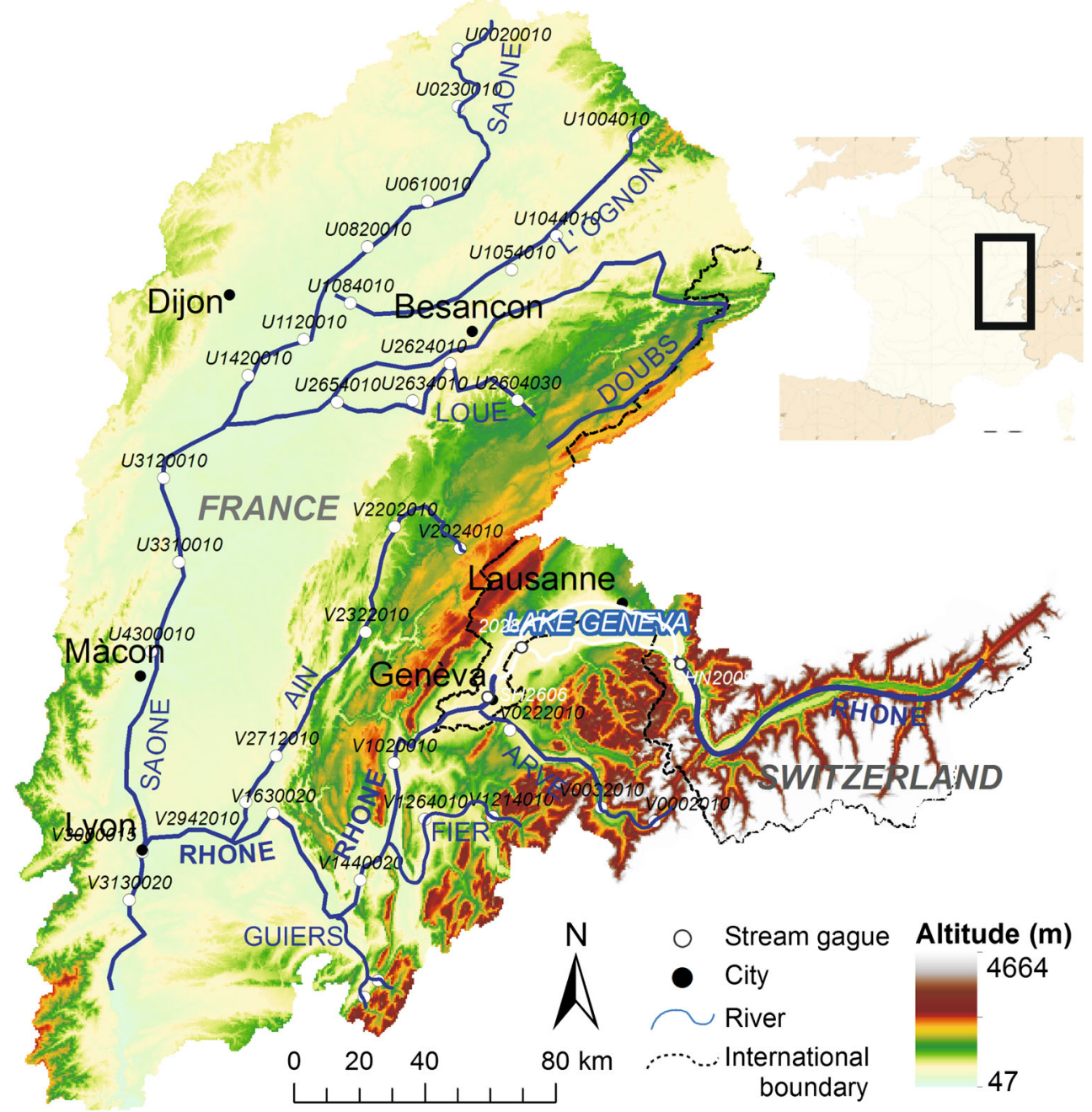

Fig. 1 Location of the study site: Swiss Rhone upstream Lake Geneva (Switzerland) and tributaries to the Rhone downstream of Geneva and down to Lyon (France). Station codes are explained in Table S1 (supplementary material)

GlobCover 2009 data were used in addition to ESDB maps; values from the FAO 56 report were obtained for the crop factor (Allen et al. 1998). To homogenise all the spatial information, each raster file was aggregated or interpolated to $500 \mathrm{~m}$ pixel size.

Meteorological data consisted of daily precipitation (rainfall and snow), temperature and evaporation values for 72 stations from SAFRAN (Quintana-Seguí et al. 2008). Discharge data were provided by the French HYDRO2 and Swiss Federal Office for the Environment (FOEN) databases, from which 37 stream gauges were selected (Table S1). Instrumental data systematically covered the period 1960-2012.

\section{Analysis of discharge data series}

The first step of the study is based on statistical analyses and aims at identifying changes in run-off regimes based on changes in seasonal behaviour of monthly Pardé coefficients (Pardé 1933). The second step was the identification of significant trends for all available time series, trends in the mean and extreme (minimum and maximum) annual run-off. Multi-temporal trend analyses in this study were conducted using the nonparametric Mann-Kendall test (MK; Yue and Wang 2002; Helsel and Frans 2006) through the multi-temporal method proposed by Hannaford et al. (2013). We provide more information about these methods in the supplementary material.

\section{Assessment of climatic change scenarios}

To include the large range between the four representative concentration pathways (RCPs), we selected the two extremes (RCP 2.6 and RCP 8.5) and analysed the whole suite of 31 CMIP5 models available for each RCP. We then downscaled GCM data (van Vuuren et al. 2011; Moss and 
Jens 2010; Taylor et al. 2012) and bias-corrected the data (Teutschbein and Seibert 2013) using the statistical deltachange approach (Smith and Pitts 1997). Following the method described in Huss et al. (2008), we obtain meteorological time series with the same resolution, characteristics and variance as in the past and for the 72 stations used in this study. This post-processing method does not, however, account for changes in the variability of the climate variables, which presumably represents a simplification of reality.

The scenarios selected for this study represent different combinations of projected air temperature, precipitation and evaporation anomalies, and they are characteristic for four combinations: (1) almost no change, (2) warm-dry, (3) wet and (4) warm-wet (future climates run closest to the 19th percentile; see Figure S2).

In addition to climatic changes, we assumed two lake management scenarios: in the first scenario, lake management and outflow will be those of the baseline period (i.e., same temporal variability and discharge as during the period 1980-2010), whereas the second scenario considers a reduction in discharge by $50 \%$. This assumption was based on Beniston (2012) who projected a decrease in the lake inflow by $50-75 \%$ due to glacier wasting and changing climate in the Swiss Rhone.

We also evaluated whether the magnitude of extreme events was likely to increase in the future. A statistical analysis of extremes was performed to basin-wide, 7-day annual maximum and minimum discharges (Hurkmans et al. 2010; Demaria et al. 2013) using a generalised extreme value (GEV) distribution function. For the 30-year period 2070-2100, we selected the annual maximum or minimum discharge and fitted the parameters of the GEV to each of the GCM scenarios using a Bayesian Markov Chain Monte Carlo approach (Reis and Stedinger 2005; Viglione 2009), which adequately defines the likelihood function and can account for uncertainties in hydrological extremes as it provides estimates of confidence bounds for the estimated quantiles.

\section{Hydrological model}

The hydrological model TETIS (Francés et al. 2007) was used to simulate run-off yield in the Rhone watershed under present and climate change conditions, transforming meteorological time series and climatic model outputs (precipitation, reference evapotranspiration and temperature scenarios) into run-off. The conceptual model was selected as it (1) has physically based parameters, (2) simulates all the main components of the land phase of the hydrological cycle and (3) is distributed in space using a regular grid. The model has been largely tested over the last 20 years, with good results in different climatic and catchment size scenarios and for floods and continuous simulation-related problems. For a detailed description of the model and applications, see Vélez et al. (2009); Salazar et al. (2013); Bussi et al. (2014).

The parameter maps were estimated a priori using all environmental available information, before correction factors were included to modify globally the estimated maps. In this way, the spatial variability captured in the initial estimated maps could be kept and a global change in magnitude of parameter maps was performed with the correction factors (Francés et al. 2007). Calibration of the hydrological model was performed using a traditional manual calibration, a simple trial-and-error approach, to define the feasible range of parameter correction factors, and thereafter, an automatic algorithm was used to find the final values. First, the model was calibrated for the entire basin using the lowermost gauge station in Lyon (Ternay). The calibration time period was 2003-2008 and includes a very wet (2005) and a dry (2003) year. To validate the efficiency of the calibration, the model was then run for the period 2008-2012. After basin-scale calibration, sub-areaspecific correction factor adjustments were carried out in a spatially distributed calibration process. Again, the efficiency of this calibration was temporally validated. Model performance of the calibration and validation periods was measured with the Nash-Sutcliffe Efficiency (NSE) coefficient (Nash and Sutcliffe 1970). In addition, we calculated the root mean squared error (RMSE) based on the differences between observed and simulated peak discharge, and the error or bias (in \%) for the observed and simulated total volumes.

\section{Results and discussion}

Long-term analysis of past discharge

At the multi-decadal scale, the temporal variability of the flow regime underwent slight changes between the 1960s and today. Part of these results is shown in Figure S1, but they are explained here. Changes in mean monthly run-off are slightly significant in some cases, and/or change in timing, and thereby point to inter-annual shifts of the dominant hydrological processes. In the Arve River, the reduction in run-off was observed mainly in summer, and it can possibly be related to advanced glacial retreat and/ or earlier snowmelt, so that discharge is reduced at a time of the year when precipitation is typically low. In addition, increased storage in the dams may also reduce summer discharge. The Ain River, with a strong pluvial and slightly nival regime, presents a reduction in run-off volumes in spring, but this reduction is slightly compensated by for increased run-off during autumn and winter. 

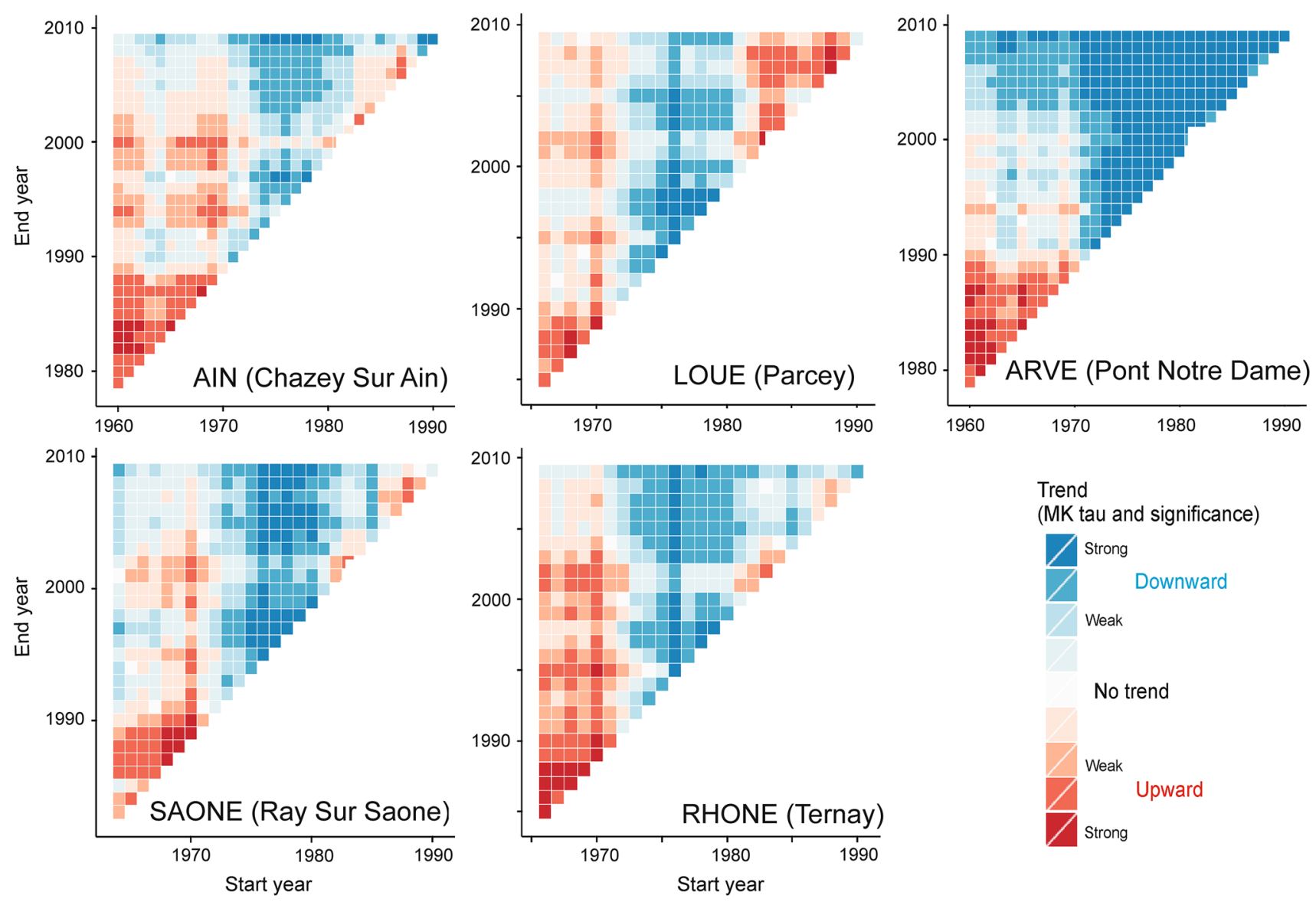

Trend

(MK tau and significance)

Strong

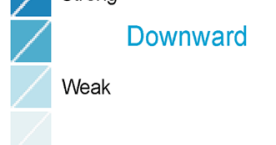

No trend

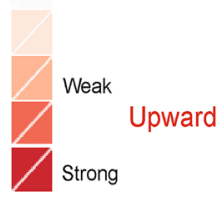

Fig. 2 Multi-temporal trend analysis for the mean discharge for several tributaries of the Rhone (for details on station names please refer to Table 1). Blue and red cells correspond to negative and positive tau values, respectively (the darker the colour, the more significant the trend)

At the outlet of the basin (Rhone at Ternay), the change in volume is not significant, but a shift can be observed in the timing of high and low flows (from winter to spring and autumn to summer, respectively). These tendencies are mainly observed from the 1980s onwards. One could assume that these differences in regimes and volumes between the 1980s and today are reflecting dam and reservoir construction. However, most of the dams in the study catchment were already operational in the 1980s, with the exception of Seujet at the outlet of Lake Geneva (1995), which does, however, impact run-off much less than the other, more conventional dams in the Alpine domains of the Rhone River.

Figure 2 shows multi-temporal trend plots for mean annual discharge and for selected sites; it points to the influence of the time window on trends and nicely illustrates the temporal variability of trends and intra-decadal variations in run-off. In general terms, one can observe significant downward tendencies for the recent period 1980-2010, whereas positive trends are present when analysis is restricted from the 1960s to the 1980s and 1990s.
The strong downward trends observed in most tributaries are not, however, continued in the Loue for the recent past, when discharge shows positive tendencies for the three hydrological variables. Similar positive patterns, but not statistically significant, become apparent in the Ain and Saone rivers for minimum discharge. While dam and reservoir constructions can partly explain the observed negative trends, climatic drivers cannot be discarded either as the patterns in the hydrological and climatic parameters are similar in the entire region. In addition, negative signals are found in low flows, particularly strong ones namely in the Arve and Ain Rivers, and negative tendencies in the Saone and Rhone Rivers. These trends and tendencies are in agreement with observations made by Renard (2006); (Giuntoli et al. 2013), who identified significant trends towards more severe low flows for south-western France and suggested that these trends may result from large-scale climate variability and its inertial behaviour.

The annual maxima show negative signals as well, with significant downward tendencies in the Arve River and less pronounced trends in the Saone, Ain and Rhone Rivers. In the case of the Arve River, the reduction in high flows can 
Table 1 TETIS model performance after calibration and validation in the French Rhone basin upstream of Lyon

\begin{tabular}{|c|c|c|c|c|c|c|c|c|}
\hline RIVER & RUN & NSE & $\begin{array}{l}\text { Max. Obs. } \\
\left(\mathrm{m}^{3} / \mathrm{s}\right)\end{array}$ & $\begin{array}{l}\text { Max. sim. } \\
\left(\mathrm{m}^{3} / \mathrm{s}\right)\end{array}$ & $\begin{array}{l}\text { RMSE } \\
\left(\mathrm{m}^{3} / \mathrm{s}\right)\end{array}$ & $\begin{array}{l}\text { Obs. Vol. }\left(\mathrm{Hm}^{3} /\right. \\
\text { year) }\end{array}$ & $\begin{array}{l}\text { Sim. Vol. }\left(\mathrm{Hm}^{3} /\right. \\
\text { year })\end{array}$ & $\begin{array}{l}\text { Error } \\
(\%)\end{array}$ \\
\hline \multirow[t]{2}{*}{ RHONE (Ternay) } & Calibration & 0.70 & 2800.00 & 3256.23 & 167.01 & $83,496.67$ & $83,302.72$ & -0.23 \\
\hline & Validation & 0.51 & $2,200.00$ & $1,979.87$ & 234.51 & $74,936.97$ & $68,840.50$ & -8.13 \\
\hline \multirow[t]{2}{*}{ AIN (Chazey sur Ain) } & Calibration & 0.66 & $1,050.00$ & 826.45 & 65.64 & $17,142.30$ & $19,107.48$ & 11.46 \\
\hline & Validation & 0.54 & 219.00 & 126.48 & 20.72 & $2,037.79$ & $1,510.75$ & -25.86 \\
\hline \multirow[t]{2}{*}{ ARVE (Pont Notre Dame) } & Calibration & 0.63 & 359.00 & 220.33 & 22.82 & $9,662.83$ & $10,006.84$ & 3.56 \\
\hline & Validation & 0.63 & 377.00 & 278.03 & 23.61 & $12,386.83$ & $12,860.16$ & 3.82 \\
\hline \multirow{2}{*}{$\begin{array}{l}\text { L’OGNON (Chassey-Les } \\
\text { Montbozon) }\end{array}$} & Calibration & 0.80 & 293.00 & 271.61 & 16.61 & $4,816.12$ & $4,514.32$ & -6.27 \\
\hline & Validation & 0.70 & 385.00 & 353.1 & 24.77 & $5,930.84$ & $4,656.06$ & -21.49 \\
\hline \multirow[t]{2}{*}{ SAONE (Ray-sur-Saone) } & Calibration & 0.65 & 507.00 & 355.93 & 36.16 & $7,773.68$ & $8,491.09$ & 9.23 \\
\hline & Validation & 0.68 & 510.00 & 401.36 & 32.38 & $7,088.76$ & $7,717.74$ & 8.87 \\
\hline \multirow[t]{2}{*}{ LOUE (Parcey) } & Calibration & 0.81 & 450.00 & 431.22 & 24.06 & $7,066.27$ & $6,226.98$ & -11.88 \\
\hline & Validation & 0.81 & 304.00 & 231.15 & 14.64 & $3,981.23$ & $4,362.94$ & 9.58 \\
\hline
\end{tabular}

NSE is the Nash-Sutcliffe coefficient; Max.Obs. and Max.Sim. are the maximum observed and simulated discharge values $\left(\mathrm{m}^{3} / \mathrm{s}\right)$ for the simulated period; RMSE is the root mean squared error of the previous values; Obs.Vol. and Sim.Vol. are the observed and simulated mean annual discharge in $\mathrm{Hm}^{3} /$ year for the period; and Error is the percentage error in total volume

be related to storage of water in dams, as well as to reduced glacier melt waters and/or earlier snowmelt (Huss 2011). The negative trend in the Ain River for the high flows could be associated with the observed reduction in run-off volume in spring (when the river typically shows maximum run-off values). The Loue River does not show any significant trends for high flows.

\section{Hydrological modelling implementation}

Before driving the TETIS model with the climate projections of precipitation, potential evaporation and temperature, it was calibrated and validated, and its performance evaluated for the most recent past (Table 1, Section S6 and Fig. S7).

The overall model efficiency is found to be high as indicated by NSE values ranging from 0.63 to 0.81 for the calibration, and from 0.51 to 0.81 for the validation periods. In most cases, the model tends to slightly underestimate total volume, but never beyond $15 \%$; the total volume is much less frequently overestimated, namely by $25 \%$ for the Ain and $21 \%$ for the L'Ognon Rivers in the validation period. The lowest NSE was found during calibration for the Ain and Arve Rivers. These basins have particular processes that have not been included in the model conceptualisation. In the Ain River flowing from the Jura Mountains, karst processes may influence hydrology (Notebaert and Piegay 2013) and these processes have not been modelled in this study. In the Arve River, flowing from the French Alps, the water storage in dams, the glacier influence and the water supply by glacier melting are not properly modelled, mainly due to limitations and deficiencies of the degree-day equation used for glaciers (Rohrer et al. 2013). Besides these discrepancies, the results obtained clearly indicate that the model can reproduce adequately the water cycle of the Rhone River and that model outputs can be used to evaluate changes in future flow events.

Climate change impact on river discharge

The comparison between historical data and climatic series for the control period was satisfactory, with the best correspondence between observations and predictions for temperature and the lowest agreement for precipitation (see section S4 and Figure S5). The estimated errors ranged from 9 to $17 \%$ for temperature, -18 and $-27 \%$ for precipitation and -0.05 and $11 \%$ for evaporation. The temporal distribution from monthly to daily was also validated for the control period and found to correctly reproduce observed daily values (see Figure S6). The final climate projections considered for analysis project a change in temperature between -8 and $+51 \%$, a reduction in precipitation in the range of -10 to $-27 \%$ and an increase in evaporation between 1.3 and $33 \%$ by the end of the twenty-first century (as compared to the control period 1980-2010).

The impacts of these changes on the Ain River, which is dominated by a pluvio-nival regime, show a change in mean annual discharge between -3 and $+34 \%$. Only one scenario (RCP $8.5 \mathrm{CSIRO}$ ) is leading to a reduction in discharge; the other three scenarios predict, by contrast, an increase in mean annual discharge. The regime is likely to change as well, with lowest discharge to occur in late summer and future maxima in spring (Fig. 3a). The 


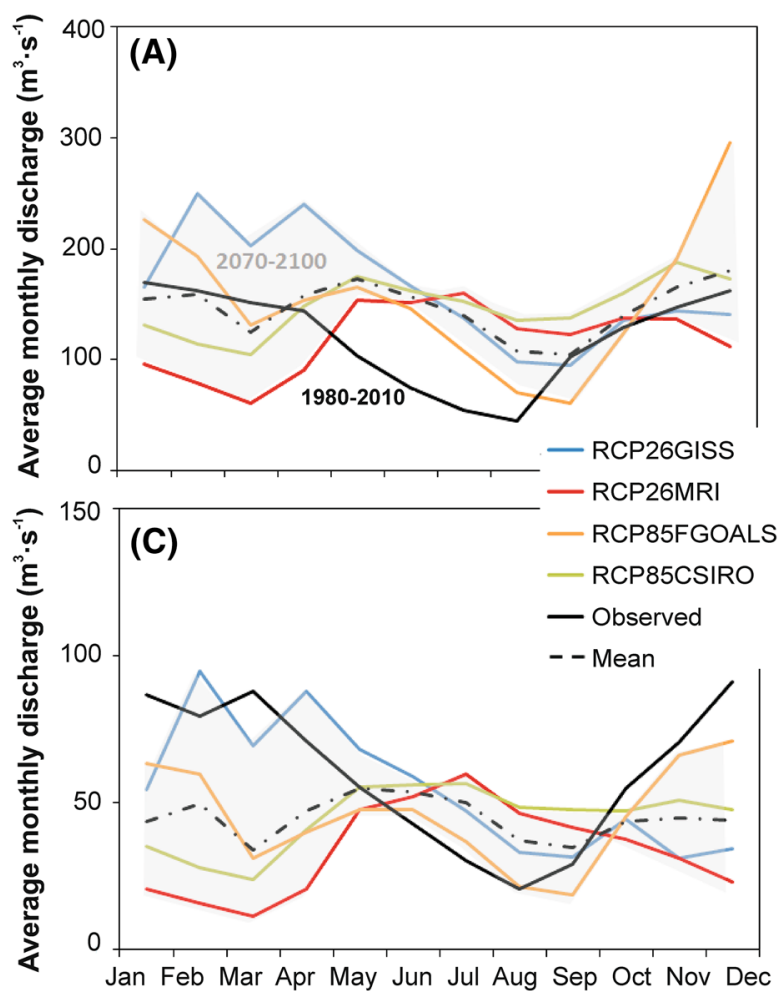

Fig. 3 Changes in monthly discharge between the recent past (1980-2010; solid black line) and the end of the century (2070-2100; dotted black line). The colour lines and shaded surfaces

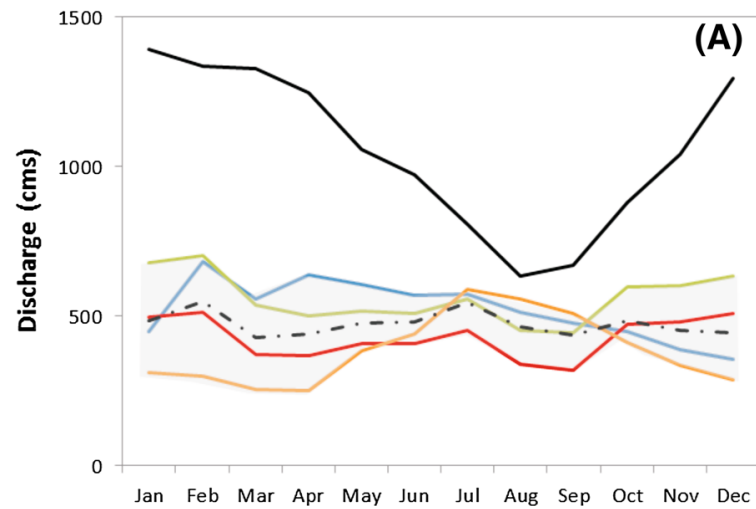

Fig. 4 Changes in monthly discharge of the Rhone River at Ternay between the baseline period (1980-2010; solid black line) and the end of the twenty-first century (2070-2100; dotted black line). Legend explained in Fig. 3. In plot (a), discharge from Lake Geneva is

analysis of extremes (Fig. 4a, b) points to larger discharge during low flows in all four scenarios, and a tendency to form larger high flows, although the latter will be affected by large variability.

In the case of the Arve River, by contrast, mean annual flows exhibit a significant reduction, with a change in seasonality of run-off (Fig. 3b). The nivo-glacial regime is expected to become more pluvial, with higher discharge
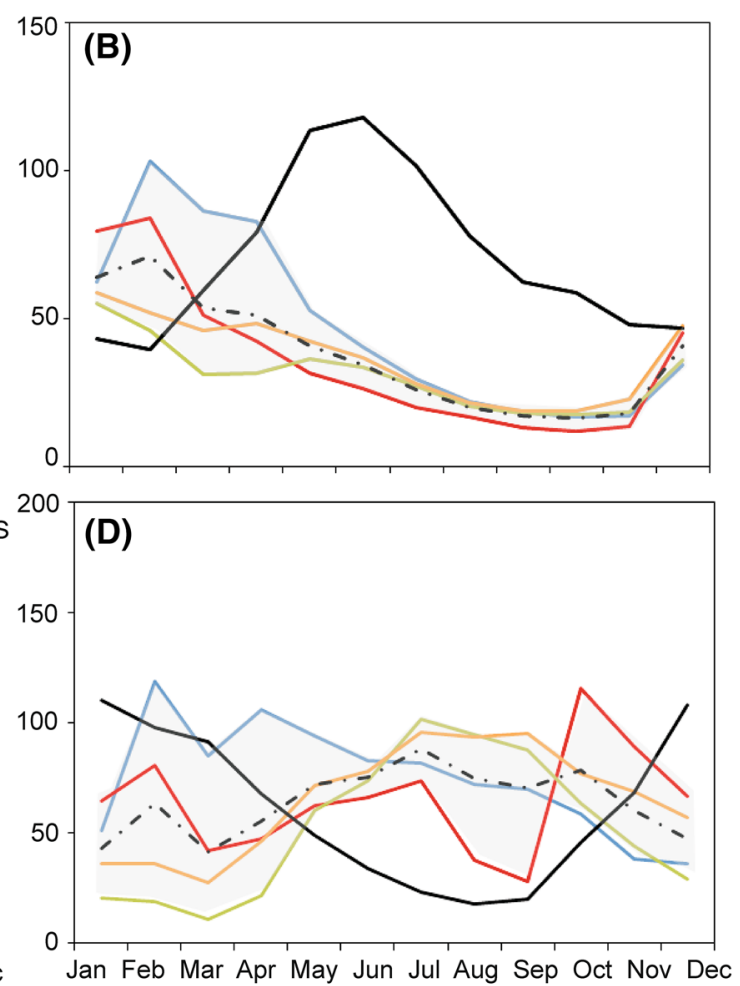

give the possible range of discharge, according to the four different scenarios selected for the analysis. a Ain; b Arve; $\mathbf{c}$ Loue and $\mathbf{d}$ Saone Rivers

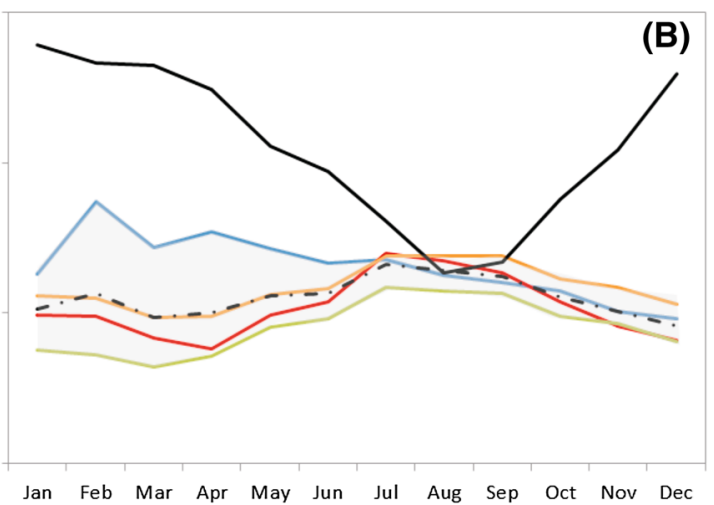

reduced by $50 \%$ as compared to current discharge to account for reduced inflow into the lake by the end of the twenty-first century; in plot (b), discharge and lake-level management are assumed to remain identical to the baseline period

values in winter and a change in mean annual discharge between -35 and $-57 \%$. This result is in agreement with Huss (2011), who predicted the glacier contribution from that catchment to be $<10 \%$ by 2100 . In general terms, regarding extremes, they are likely to be enhanced by the end of the century, with more extreme low flows and more extreme high flows, but again with larger values for high return periods (Fig. 4c, d). 
For the Loue River (at Parcey), models predict a reduction in mean discharge ranging from -9 to $-43 \%$, with a smoothed regime, as well as shifts in the seasonality of flows (Fig. 3c). Future extremes show a similar behaviour as in the Arve River, with an increase in both low and high flows (Fig. 4e, f).

The projections for the Saone River (at Ray-sur-Saone) are not uniform. We observe changes in the mean discharge between -14 and $22 \%$ with only one scenario predicting a decrease in mean annual flows. A shift exists in seasonality with higher flows being expected in future summers (Fig. 3d). As a consequence, one may also expect less severe low flows, whereas for high flows, variability is much higher as compared to the rivers illustrated above. The overall tendency is for a decrease, but with large uncertainties in the model runs, in particular for rare extreme floods, where an increase seems possible (Fig. 4g, h).

As can be seen in Fig. 3, largest variability in the projections typically occurs in January, February and March, reflecting the large variability in the timing of snowmelt processes. Scenario discrepancy tends to decrease in summer when run-off will increasingly depend on precipitation.

At Lyon, the reduction in mean annual flows is projected to be between -46 and $-63 \%$ by the end of the century and for the scenario in which run-off from Lake Geneva is reduced by $50 \%$ (Table $\mathrm{S} 2$ ). The reduction is in the order of -38 to $-57 \%$ in case that outlet discharge of Lake Geneva would remain unchanged (Table S3). Similar reductions were described for different rivers over France by (Boé and Habets 2014) and Chauveau et al. (2013), where a general reduction in annual stream flow of about -25 and $-35 \%$ was projected for the horizon 2065. The reduction in mean annual flow will likely be accompanied by a shift in the seasonality of flows and by a smoothening in the regime (Fig. 4). The main difference between the two lake management scenarios concern low flows, which would become more pronounced in the future as outflow from Lake Geneva is unlikely to be maintained at the current discharge.

Peak flows (low and high) also point to a decrease by the end of the century as compared to today were, but this reduction is less significant when outlet discharge from Lake Geneva is maintained at its current level.

The frequency analysis of the extremes (Fig. 5) also revealed that minor changes can be expected in the magnitude of maximum discharge, but that a decrease in low flows could occur between the baseline period (1980-2010) and the second half of the twenty-first century for small return periods (1.5 and 5 years). For extreme flows with much longer return periods, however, the range of future evolutions is larger, including a possible increase in extreme floods and a decrease in low flows. The observed noticeable increase in dispersion for large return periods also indicates an increment in uncertainty.

Therefore, a unique result cannot be obtained regarding extreme flows, but a clear tendency exists for more extreme peaks for both low and high flows at Ternay by the end of the century.

In summary, discharge at Ternay is likely to decrease significantly by the end of the century, low flows will become more extreme, whereas less severe low flows can be expected in the rest of the sub-basins. With respect to floods, high flows show a general tendency of decrease and possible upwards are limited to the more extreme, yet less frequent floods (Table S3).

These findings are in agreement with results of the ACQWA (Beniston et al. 2011) and Explore2070 and other projects in France (Boé and Habets 2014; Chauveau et al. 2013), yet new lines of evidence could be added to our understanding of discharge in this transboundary catchment. The Swiss and French sub-basins have been linked through the inclusion of the management scheme of Lake Geneva and may thus better assist long-term governance issues of water rights and concessions in this international context. The work also differs by the nature of model generations used and with respect to the magnitude of changes, which is, however, also due to the different time windows for the baseline and the projections. The lack of common scenarios makes a direct comparison difficult. While we predict precipitation to decrease by 10-27\%, Explore2070 portrays a more drastic decrease by up to $37 \%$. Despite the differences in magnitude changes, impacts on discharge seem largely consistent. In Explore2070, discharge in the Rhone River at Lyon (Pont Morand) is predicted to drop by up to $-54 \%$, especially in summer (June-September) when outlet discharge from Lake Geneva could possibly play an important role. In this light, the inclusion of lake management in the analysis represents an important contribution to a better understanding of the transboundary context of the Rhone River.

\section{Uncertainty assessment}

One of the main sources of uncertainties is due to the physical parameterisations and the assumptions made by the GCM. The RCPs should not be interpreted as forecasts or absolute bounds, or be seen as a policy prescriptive. The RCPs describe a set of possible developments in emissions and land use, based on consistent scenarios (van Vuuren et al. 2011).

The following step in the modelling process was the downscaling. As pointed out by Chen et al. (2011), the choice of a downscaling method is critical for any climate change impact study on hydrology. The strength and weaknesses of the delta-change method have been 

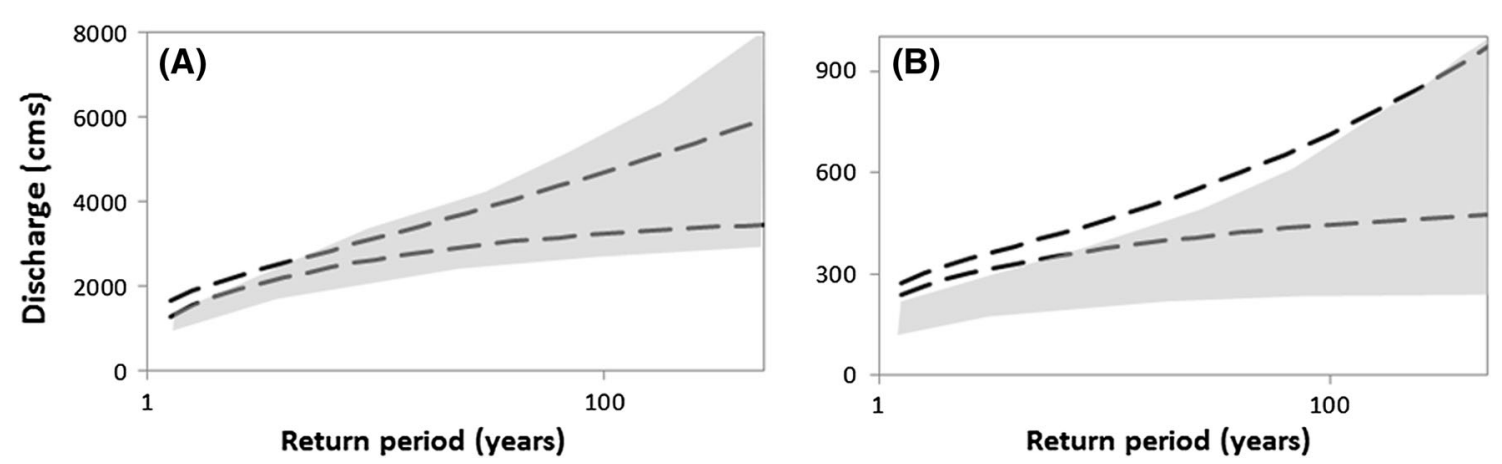

Fig. 5 Frequency analysis for the observed annual maximum (a) and minimum (b) (black dotted confidence intervals) and frequency of the projected discharges (grey shading)

discussed in several papers (Fowler et al. 2007; Sajjad Khan et al. 2006). Its main weakness is that it does not modify the occurrence of future variability. In this respect, Boé and Habets (2014) suggested that the multi-decadal variations in river flows are expected to be mostly internal. They therefore have to be taken into account as potential uncertainties in climate change projections and in adaptation policies to climate change. As one cannot simply suppose that those variations will have the same amplitudes in the perturbed climate as in the instrumental period (the amplitude of low-frequency variations is not necessarily independent of the mean climate state), one has to rely on multiple members of climate projections to estimate those uncertainties.

Once the projected data series are obtained, they were used as input data for the hydrological modelling. We first calibrated and validated the model, in a two-step calibration (at the outlet and in several sub-basins). The model performance was generally good with some differences between the entire basin and the smaller sub-basins. Several factors lead to the different results for the large basins. In the large basins, some errors in the upstream basin can be compensated for downstream, leading to overall better results. The same kind of compensation can occur for the description of the geological and surface properties. An additional reason could be that the human activities (dams, derivation, pumping, etc.) can have relatively larger effect on the small basin discharge. Finally, larger errors may be due also to the faster hydrological response of those basins, which cannot be reproduced by the relatively simple river routing model used herein.

Transboundary governance of the Rhone in a climate of changes

The modifications in run-off in the Rhone River from Lake Geneva to Lyon might have important impacts for many different water users on either side of the borders shared between France and Switzerland. It might lead to an increase of use rivalries between the different sectors using water resources (such as hydropower, agriculture, cooling of nuclear plants, production of drinking water or ecosystem) for their own purposes.

The management of these tensions is a particular issue in the present context of transboundary area characterised by the multiplicity of institutional levels and frameworks. Moreover, this strong fragmentation is reinforced by important delegation of competences to hydropower producers. Indeed, concession contracts have been signed for periods of 60-90 years on the two sides of the border, and by doing so, operational management of the Rhone River depends to a great extent from private operators aiming to produce electricity.

In this context, the increase in extreme events (and notably several important droughts occurring since the early 2000) urges public actors on returning on the centre of the stage and on redefining governance modalities of the river. Therefore, public actors try to find solutions to overcome the strong institutional fragmentation linked to the transboundary setting. They also aim to ensure stronger adaptive capacities by anticipating and answering potential tensions within actors' configuration.

Thus, this study has to be seen in the context of a transboundary river governance system under construction. Therefore, the definition of tendencies and scenarios of flow modifications are crucial, even in the long-term illustrated in this paper. The approach of this contribution has thus been designed in a way to support a decisionmaking process in this context of changes and takes into account some degree of uncertainty inherent to the definition of climatic scenarios as well as the future management of Lake Geneva's water. We believe that such an approach might help to reflect on the governance modalities of a river such as the Rhone, especially when water management significantly depends on concession contracts granted for several decades. 
Acknowledgments This work has been realised within the GOUVRHONE-hydropower and the regulation of the Rhone River in a context of climate change and electricity liberalisation project and was funded by the French Ministry of Ecology, the French Water Agency Rhone Méditerranée and Corse, the Swiss Federal Office for the Environment, the cantons of Geneva and Vaud, the Services Industriels de Genève and Electricité de France. The authors acknowledge the substantial support and feedback of Christophe Corona, Samuel Morin, Xavier Rodriguez Lloveras, Mario Rohrer and Annina Sorg.

\section{References}

Allen RG, Pereira LS, Raes D, Smith M (1998) Crop evaporation: Guidelines for computing crop requirements. Irrigation and Drainage Paper No. 56 FAO Rome, Italy

Beniston M (2012) Impacts of climatic change on water and associated economic activities in the Swiss Alps. J Hydrol 412-413:291-296. doi:10.1016/j.jhydrol.2010.06.046

Beniston M, Stoffel M (2013) Assessing the impacts of climatic change on mountain water resources. Sci Total Environ. doi:10. 1016/j.scitotenv.2013.11.122

Beniston M, Stoffel M, Hill M (2011) Impacts of climatic change on water and natural hazards in the Alps: can current water governance cope with future challenges? examples from the European "ACQWA" project. Environ Sci Policy 14(7):734-743. doi:10.1016/j.envsci.2010.12.009

Boé J, Habets F (2014) Multi-decadal river flow variations in France. Hydrol Earth Syst Sci 18:691-708

Bréthaut C, Pflieger G (2013) The shifting territorialities of the Rhone River's transboundary governance: a historical analysis of the evolution of the functions, uses and spatiality of river basin governance. Reg Environ Change. doi:10.1007/s10113-0130541-4

Bussi G, Frances F, Horel E, Lopez-Tarazon JA, Batalla RJ (2014) Modelling the impact of climate change on sediment yield in a highly erodible Mediterranean catchment. J Soils Sediments. doi:10.1007/s11368-014-0956-7

Demaria EMC, Maurer EP, Thrasher B, Vicuña S, Meza FJ (2013) Climate change impacts on an alpine watershed in Chile: do new model projections change the story? J Hydrol 502:128-138

Deneux M (2002) Rapport sur l'évaluation de l'ampleur des changements climatiques, de leurs causes et de leur impact prévisible sur la géographie de la France à l'horizon 2025, 2050 et 2100 . Office parlementaire d'évaluation des choix scientifiques et technologiques, Paris $291 \mathrm{p}$

Etchevers P (2002) Impact of a climate change on the Rhone river catchment hydrology. J Geophys Res 107(D16):4293. doi:10. 1029/2001JD000490

Francés F, Vélez JI, Vélez JJ (2007) Split-parameter structure for the automatic calibration of distributed hydrological models. J Hydrol 332:226-240

Giuntoli I, Renard B, Vidal JP, Bard A (2013) Low flows in France and their relationship to large-scale climate indices. J Hydrol 482:105-118

Gobiet A, Kotlarski S, Beniston M, Heinrich G, Rajczak J, Stoffel M (2013) Twenty-first century climate change in the European Alps-A review. Sci Total Environ. doi:10.1016/j.scitotenv.2013. 07.050

Hannaford J, Buys G, Stahl K, Tallaksen LM (2013) The influence of decadal-scale variability on trends in long European streamflow records. Hydrol Earth Syst Sci 17:2717-2733
Helsel DR, Frans LM (2006) Regional Kendall test for trend. Environ Sci Technol 1:4066-4073

Hurkmans et al (2010) Changes in streamflow dynamics in the Rhine Basin under three high-resolution regional climate scenarios. Am Meteorol Soc. doi:10.1175/2009JCLI3066.1

Huss M (2011) Present and future contribution of glacier storage change to runoff from macroscale drainage basins in Europe. Water Resour Res. doi:10.1029/2010WR010299

Huss M, Farinotti D, Bauder A, Funk M (2008) Modelling runoff from highly glacierized alpine drainage basins in a changing climate. Hydrol Process 22:3888-3902

Husting P, Jouzel J, Le Treut H (eds) (2005) Changements climatiques, quels impacts en France. Greenpeace, Paris, p 139

Moss T, Jens N (2010) Multilevel water governance and problems of scale: setting the stage for a broader debate. Environ Manag 46(1):1-6

Nakicenovic N, Nakicenovic N, Davidson O, Davis G, Grübler A, Kram T, Rovere ELL, Metz B, Morita T, Pepper W, Pitcher H, Sankovski A, Shukla P, Swart R, Watson R, Dadi Z (2000) Special report on emissions scenarios, international panel on climate change. Cambridge University Press, Cambridge, UK

Nash JE, Sutcliffe JV (1970) River flow forecasting through conceptual models, part I-a discussion of principles. J Hydrol 10:282-290

Notebaert B, Piegay H (2013) Multi-scale factors controlling the pattern of floodplain width at a network scale: the case of the Rhône basin. Geomorphology, France. doi:10.1016/j.geomorph. 2013.03.014

Panagos P (2006) The European soil database. GEO: connexion $5(7): 32-33$

Pardé M (1933) Le régime des cours d'eau de l'Europe orientale (en collaboration avec St.Kolupaila). Revue Geographie Alpine, T.XXI (IV), pp. 651-748

Quintana-Seguí P, Le Moigne Y, Durand E, Martin F, Habets M, Baillon C, Canellas L, Franchisteguy L, Morel S (2008) Analysis of near-surface atmospheric variables: validation of the SAFRAN analysis over France. J Appl Meteorol Climatol 47:92-107

Rahman K, Maringanti C, Beniston M, Widmer F, Abbaspour K, Lehmann A (2012) Streamflow modeling in a highly managed mountainous glacier watershed using SWAT: the upper Rhone River watershed case in Switzerland. Water Resour Manag. doi:10.1007/s11269-012-0188-9

Redaud JL, Noilhan J, Gillet M, Huc M, Begni G (2002) Changement climatique et impact sur le regime des eaux en France. Mission Interministérielle sur l'effet de serre (MEDD), France $41 \mathrm{p}$

Reis DS, Stedinger JR (2005) Bayesian MCMC flood frequency analysis with historical information. J Hydrol 313:97-116

Renard B (2006) Détection et prise en compte d'éventuels impacts du changement climatique sur les extrêmes hydrologiques en France. Thèse de doctorat, INP Grenoble $361 \mathrm{p}$

Rohrer M, Salzmann N, Stoffel M, Kulkarni AV (2013) Missing (in situ) snow cover data hampers climate change and runoff studies in the Greater Himalayas. Science Total Environ 468-469(Suppl):S60-S70

Salazar S, Francés F, Komma J, Blume T, Francke T, Bronstert A, Blöschl G (2013) A comparative analysis of the effectiveness of flood management measures based on the concept of "retaining water in the landscape" in different European hydro-climatic regions. Nat Hazards Earth Sys Sci 12:3287-3306

Smith JB, Pitts G (1997) Regional climate change scenarios for vulnerability and adaptation assessments. Clim Change 36:3-21

Taylor KE, Stouffer RJ, Meehl GA (2012) An Overview of CMIP5 and the experiment design. Bull Amer Meteor Soc 93:485-498

Van Vuuren DP, Edmonds J, Kainuma M, Riahi K, Thomson A, Hibbard K, Hurtt GC, Kram T, Krey V, Lamarque JF, Masui T, 
Meinshausen M, Nakicenovic N, Smith SJ, Rose SK (2011) The representative concentration pathways: an overview. Clim Change 109:95-116

Vélez JJ, Puricelli M, López Unzu F, Francés F (2009) Parameter extrapolation to ungauged basins with a hydrological distributed model in a regional framework. Hydrol Earth Sys Sci $13: 229-246$
Viglione A (2009) nsRFA: non-supervised regional frequency analysis. R package, Version 0.6-9. http://cran.r-project.org/ web/packages/nsRFA. (accessed 24 Aug 2009; published 19 Aug 2009)

Yue S, Wang CY (2002) Applicability of prewhitening to eliminate the influence of serial correlation on the Mann-Kendall test. Water Resour Res 36:1068 